\title{
Effect of dietary coenzyme Q10 supplementation on the growth rate, carcass characters and cost effectiveness of broiler fed with three energy levels
}

\author{
Marappan Gopi", Manika Ragavan Purushothaman and Dooraisamy Chandrasekaran
}

\begin{abstract}
The objective of this experiment was to study the effect of dietary supplementation of Coenzyme Q10 on broiler growth rate, carcass characteristics and cost of production. A biological trial was carried out with 270 broiler chicks fed with coenzyme Q10 at 0, 20 and $40 \mathrm{mg} / \mathrm{kg}$ of diet at each of the three energy levels. At the end of 42 days growth period the birds were sacrificed and the samples were analysed. Feed intake was comparable in all the energy and CoQ10 combinations, but higher body weight gain and better feed efficiency with less feed cost per kilogram weight gain was observed in high energy group supplemented with $20 \mathrm{mg}$ of CoQ10/kg diet. The dressing percentages, weight of giblet, liver, spleen, abdominal fat, intestinal length were not significantly altered by CoQ10 supplementation. The heart weight, gizzard weight and ascites heart weight (AHI) were significantly decreased due to CoQ10 supplementation. Hence, birds fed with high energy diet supplemented with $20 \mathrm{mg}$ CoQ10 per kg of diet had higher production performance.
\end{abstract}

Keywords: Body weight gain; Coenzyme Q10 (CoQ10); Cost effectiveness; Energy levels; Feed efficiency

\section{Introduction}

The growth rate of broilers has increased over the decades as a result of continuous selective breeding by the broiler breeders (Schmidt et al. 2009). Feeding and management systems for this level of production had to be developed concurrently to exploit the full genetic potential. To achieve this, the poultry nutritionist attempt to increase the density of the nutrients in the diet. This leads to increased oxidative stress on the broilers and depresses the growth performance (Shi-bin et al. 2007). Oxidative stress occurs when there is an imbalance between the production of oxygen radicals and antioxidants in the body. Reactive oxygen species (ROS) are mainly mitochondrial derived and directly affects the vascular remodeling and also causes pulmonary hypertension and growth rate (Bautista-Ortega et al. 2010). Broilers fed to an energy dense diet were more susceptible to oxidative stress (Cardoso et al. 2010), whereas restricted feeding decreases oxidative damage (Ozkan et al. 2010). However, an early feed restriction has severely affected the growth performance and lipid

\footnotetext{
* Correspondence: getgopi72@gmail.com

Department of Animal Nutrition, Veterinary College and Research Institute, Namakkal, India
}

metabolism in broilers (Zhan et al. 2007; Saber, et al. 2011). To overcome this oxidative stress due to nutrient dense diets, few dietary additives like anti-stress - vitamins, minerals, antioxidants (lycopene, lutein), herbals like Withania somnifera (aswagantha), Ocimum tenuiflorum (tulsi), etc. have been tried with varying degree of success. Hence, there is a need for use of compounds which might protect the birds from oxidative stress and with better nutrient utilization efficiency. One such unique compound is Coenzyme Q10 (CoQ10) which involved in mitochondrial oxidative phosphorylation and also acts as an antioxidant.

Coenzyme Q10, a naturally occurring lipophilic antioxidant, present in the mitochondria of all body cells. Being a lipid-soluble compound, it is involved in the mitochondrial adenosine triphosphate (ATP) production - bioenergetics (Geng et al. 2004a). Geng et al. (2007) observed a significantly higher body weight gain in broilers when CoQ10 was supplemented at $40 \mathrm{mg} / \mathrm{kg}$ of diet with comparable feed intake and feed efficiency. Huang et al. (2011) supplemented CoQ10 at 20 and $40 \mathrm{mg} / \mathrm{kg}$ of broiler diet and had significantly better body weight gain upto 21 days of age. Nakamura et al. (1996) got an increased survival rate and low ascites mortality when he supplemented CoQ9 at 0.2

\section{望}


per cent in broiler diet than the non-supplemented group and the body weight at 56 days and feed efficiency were not significant. CoQ10 in its reduced form acts as a free radical scavenger (Forstmark-Andre et al. 1997) and preferred over $\alpha$-tocopherol (Tang et al. 2001). Its major function in the blood is as an antioxidant (Alleva et al. 1997). CoQ10 is involved in the prevention of lipid peroxidation and also in regeneration of the other endogenous antioxidants (Navas et al. 2007). Serum or liver malonaldehyde (MDA) a product of lipid peroxidation was significantly decreased by CoQ10 supplementation (Geng et al. 2004a), indicative lipid peroxidation prevention. The activity of superoxide dismutase (SOD) was found to increase in CoQ10 supplementation at $40 \mathrm{mg} / \mathrm{kg}$ in broiler diet (Geng et al. 2004b; Huang et al. 2011) and in rats (Lakomkin et al. 2005) and anti-ROS capacity in broilers was increased by CoQ10 supplementation (Geng et al. 2004b). In broilers, only few studies using CoQ10 have been conducted with the objective of reducing ascites mortality in temperate regions. This study was carried out under prevailing local conditions where the cost of energy is very high and heat stress is chronic to know whether supplementation of CoQ10 could able to meet both these factors.

\section{Materials and methods}

\section{Birds and diets}

All procedures in the experiment were in carried out in accordance with the Institutional Animal Ethics Committee and conformed to the "Guidelines for the Care and Use of Animals in Research". The experiment was carried out during the month of October to December. The daily maximum and minimum temperature and relative humidity inside the experimental shed during the experimental period was recorded and temperature humidity index was calculated as per Tao and Xin (2003)

$$
\mathrm{THI}_{\text {broilers }}=0.85 \times \mathrm{T}_{\mathrm{db}}+0.15 \mathrm{XT}_{\mathrm{wb}}
$$

where, $\mathrm{THI}=$ temperature humidity index, ${ }^{\circ} \mathrm{C}, \mathrm{T}_{\mathrm{db}}=$ drybulb temperature, ${ }^{\circ} \mathrm{C}, \mathrm{T}_{\mathrm{wb}}=$ wet-bulb temperature, ${ }^{\circ} \mathrm{C}$. The mean maximum and minimum temperatures, relative humidity and temperature humidity index (THI) are presented in Table 1. The temperature, relative humidity and THI inside the experimental house during the trial period ranged from $19.69-32.31^{\circ} \mathrm{C}, 44.08-76.29$ per cent and $24.46-31.07^{\circ} \mathrm{C}$ respectively. The experiment was carried out with 270 day - old Cobb 400 broiler chicks which consist of nine treatments with three replicates each containing ten chicks. Feed grade coenzyme Q10 (Qzyme ${ }^{\circ}$, manufactured by Agranco, USA Code No. DV100-12) was obtained and its activity was estimated based on the method described by Vicas et al. (2009) against standard CoQ10 obtained from Sigma. The CoQ10 preparation used in this biological trial was quantified for CoQ10 and it was found to be 205 units or $205 \mathrm{mg}$ per gram. The treatment includes three levels of CoQ10 namely 0,20 and $40 \mathrm{mg} / \mathrm{kg}$ of diet each at three energy levels namely normal energy (NE) as specified by the breeder, low energy - LE (normal energy minus $100 \mathrm{kcal} / \mathrm{kg}$ of diet) and high energy - HE (normal energy plus $100 \mathrm{kcal} / \mathrm{kg}$ of diet). The treatments were labelled as NE without CoQ10, LE without CoQ10, HE without CoQ10 and 20 and $40 \mathrm{mg}$ of CoQ10 supplemented in the above three levels of energy diet. All diets contain same levels of calorie: protein, calorie: lysine and calorie: methionine ratio. The ingredients and nutrient compositions were shown in the Table 2 .

\section{Production parameters}

The birds were reared under deep litter system and maintained under standard managemental practices for a period of 42 days. The individual body weight and replicate feed intake were recorded at day one, weekly intervals and body weight gain and feed efficiency were worked out. At the end of 42 days of growth period, nine male birds per treatment (three birds per replicate) were randomly selected sacrificed. The pre-slaughter, dressed, giblet, spleen, heart and abdominal fat weights and intestinal length were recorded. The right and left ventricles were separated and weighed. The ascites heart index was calculated using Huchzermeyer and Ruyck (1986) equation method.

\section{Ascites Heart Index (AHI) \\ $=$ weight of the right ventricle/weight of total ventricle}

Production score was used as an index in the production of broiler chickens (Suzuki and Shibata 1989). It was calculated as follows:

Table 1 Temperature, relative humidity and temperature humidity index inside the experimental house

\begin{tabular}{|c|c|c|c|c|c|c|c|c|c|c|}
\hline \multirow{2}{*}{ Period } & \multicolumn{2}{|c|}{ Temperature $\left({ }^{\circ} \mathrm{C}\right)$} & \multicolumn{2}{|c|}{ Relative humidity (\%) } & \multicolumn{2}{|c|}{ Morning $\left({ }^{\circ} \mathrm{C}\right)$} & \multicolumn{2}{|c|}{ Evening $\left({ }^{\circ} \mathrm{C}\right)$} & \multicolumn{2}{|c|}{ Temperature-Humidity Index $\mathrm{THI}\left({ }^{\circ} \mathrm{C}\right)$} \\
\hline & Max. & Min. & Max. & Min. & Dry bulb & Wet bulb & Dry bulb & Wet bulb & Morning & Evening \\
\hline 0-2 weeks & 29.46 & 22.21 & 76.29 & 61.57 & 25.86 & 23.21 & 29.43 & 24.07 & 25.46 & 28.63 \\
\hline 3-4 weeks & 31.80 & 20.67 & 71.47 & 48.07 & 25.64 & 21.93 & 31.43 & 23.21 & 25.08 & 30.20 \\
\hline 5-6 weeks & 32.31 & 19.69 & 74.00 & 44.08 & 24.93 & 21.80 & 32.33 & 23.93 & 24.46 & 31.07 \\
\hline
\end{tabular}


Table 2 Ingredients and nutrients composition (\% DM) of different broiler diets

\begin{tabular}{|c|c|c|c|c|c|c|c|c|c|}
\hline \multirow[t]{2}{*}{ Ingredients (\%) } & \multicolumn{3}{|c|}{$0-2$ Weeks } & \multicolumn{3}{|c|}{ 3-4 Weeks } & \multicolumn{3}{|c|}{ 5-6 Weeks } \\
\hline & NE & LE & $\mathrm{HE}$ & NE & LE & $\mathrm{HE}$ & $\mathrm{NE}$ & LE & $\mathrm{HE}$ \\
\hline Maize & 54.2 & 58.96 & 49.88 & 53.9 & 60.4 & 50.5 & 57.22 & 62.0 & 52.79 \\
\hline DORB & 0.07 & 0.13 & 0.035 & 0.36 & 0.081 & 1.10 & 0.00 & 0.00 & 0.89 \\
\hline SOYA & 39.58 & 36.58 & 41.78 & 37.5 & 32.3 & 37.9 & 32.58 & 29.99 & 34.26 \\
\hline Rice bran Oil & 2.12 & 0.00 & 4.30 & 4.24 & 2.13 & 6.30 & 5.86 & 3.61 & 8.00 \\
\hline Calcite & 1.54 & 1.83 & 1.53 & 1.52 & 1.50 & 1.50 & 1.73 & 1.77 & 1.48 \\
\hline DCP & 0.90 & 0.92 & 0.88 & 0.95 & 1.01 & 0.94 & 1.10 & 1.12 & 1.05 \\
\hline Salt & 0.180 & 0.163 & 0.181 & 0.181 & 0.164 & 0.182 & 0.184 & 0.166 & 0.184 \\
\hline Lysine & 0.298 & 0.319 & 0.302 & 0.150 & 0.220 & 0.189 & 0.167 & 0.187 & 0.168 \\
\hline Methionine & 0.304 & 0.293 & 0.319 & 0.283 & 0.282 & 0.315 & 0.272 & 0.257 & 0.293 \\
\hline Threonine & 0.00 & 0.035 & 0.035 & 0.00 & 0.00 & 0.00 & 0.018 & 0.028 & 0.018 \\
\hline \multicolumn{10}{|l|}{ Nutrients (\%) } \\
\hline Crude protein & 22.65 & 21.80 & 23.30 & 21.65 & 20.35 & 21.75 & 19.70 & 19.00 & 20.21 \\
\hline Metabolisable Energy $(\mathrm{Kcal} / \mathrm{kg})^{*}$ & 3000 & 2900 & 3100 & 3125 & 3025 & 3225 & 3250 & 3150 & 3350 \\
\hline Calcium & 0.96 & 0.96 & 0.96 & 0.95 & 0.95 & 0.95 & 0.90 & 0.90 & 0.90 \\
\hline Available phosphorus & 0.45 & 0.45 & 0.45 & 0.47 & 0.47 & 0.47 & 0.46 & 0.46 & 0.46 \\
\hline Lysine* & 1.42 & 1.37 & 1.47 & 1.25 & 1.21 & 1.29 & 1.14 & 1.10 & 1.18 \\
\hline Methionine* & 0.62 & 0.60 & 0.64 & 0.59 & 0.57 & 0.61 & 0.55 & 0.53 & 0.57 \\
\hline
\end{tabular}

Mineral mixture addition at $0.1 \%$ supplied (in $\mathrm{mg}$ ) manganese-91, zinc - 91, iron-85, iodine- 1.82 , copper -30.24 and cobalt - 0.365 . Vitamin premix added at $0.5 \mathrm{~g}$ per $\mathrm{kg}$ feed supplied vitamin A-16500 IU, $\mathrm{B}_{2}-13 \mathrm{mg}, \mathrm{D}_{3}-3200 \mathrm{IU}$ and vitamin $\mathrm{K}-2 \mathrm{mg}$, thiamine $-5 \mathrm{mg}$, pyridoxine $-8 \mathrm{mg}$, Niacin $-320 \mathrm{mg}, \mathrm{cyanocobalamine}-0.05 \mathrm{mg}$, vitamin E $-95 \mathrm{mg}$, calcium D pantothenate $-27.5 \mathrm{mg}$ and folic acid $-14 \mathrm{mg}$, calcium $-30.1 \mathrm{mg}$. Coccidiostat added at $0.5 \mathrm{~g}$ per $\mathrm{kg}$ feed supplied $125 \mathrm{mg}$ of Di-nitro-ortho-toluamide. Antibiotic (10\% Oxy tetracycline) $0.5 \mathrm{~g}$ was added per $\mathrm{kg}$ of feed.

*Calculated values.

$$
\begin{aligned}
& \text { Production score } \\
& =\frac{\text { Average body weight in kilogram } \times \text { Survival rate in per cent }}{\text { Average market age in day } \times \text { Feed conversion }} \\
& \quad \times 100
\end{aligned}
$$

The economics of raising broilers upto six weeks with different levels of CoQ10 supplementation and nutrient density was calculated based on the actual cost of feed per $\mathrm{kg}$ weight gain.

\section{Statistical analyses}

The data collected on various parameters were analysed by one way ANOVA method as per the method of Snedecor and Cochran (1989) and the means of different experimental groups were tested for statistical significance $(\mathrm{P}<0.05)$ by Duncan's multiple range test (Duncan 1955).

\section{Results}

\section{Production performance}

The effect of CoQ10 levels and energy levels on the body weight gain, feed intake, feed efficiency and production score at biweekly intervals and overall (0 to 6 weeks) growth period are presented in Tables 3, 4 and 5 respectively.

In the 0-2 week's growth phase, the feeding of CoQ10 at $20 \mathrm{mg} / \mathrm{kg}$ in high energy diet had significantly higher body weight gain than the unsupplemented groups and normal and low energy birds fed with 20 or $40 \mathrm{mg} / \mathrm{kg}$ of CoQ10. During the 3-4 week's growth phase, there was no significant difference in body weight gain due to the CoQ10 supplementation at each energy level. However, in the 5-6 week's growth phase and 0-6 week's growth period supplementation of CoQ10 at either of the levels did not improve the body weight gain over the respective unsupplemented groups. The body weight gain ( $0-6$ weeks) was significantly higher in high energy diet supplemented with $20 \mathrm{mg}$ of CoQ10/kg (2129 g) when compared to the other energy (1900 to $1987 \mathrm{~g}$ ) and CoQ10 levels except for high energy unsupplemented group (2062 g).

During the entire growth period there was no effect of CoQ10 at different energy levels on feed intake and feed efficiency. In the 5-6 weeks growth phase, the supplementation at both the levels of CoQ10 (20 and $40 \mathrm{mg} / \mathrm{kg}$ ) did not alter the feed intake over the unsupplemented group. However, supplementation of CoQ10 in low energy diet at both the levels (20 and $40 \mathrm{mg} / \mathrm{kg}$ ) reduced the feed intake and it was comparable to the normal and high energy diets. In the finisher phase, supplementation at both the levels of CoQ10 did not alter the feed efficiency over the respective unsupplemented groups. The production score was not significantly affected by CoQ10 supplementation over the 
Table 3 Influence of Coenzyme Q10 and energy each at three levels on body weight gain (g) and production score at different growth phases

\begin{tabular}{cccccc}
\hline Treatments & $\mathbf{0 - 2}$ weeks & $\mathbf{3 - 4}$ weeks & $\mathbf{5 - 6}$ weeks & 0-6 weeks & Production Score \\
\hline $\mathrm{NE}$ & $258^{\mathrm{abc}} \pm 07$ & $672 \pm 23$ & $1007^{\mathrm{a}} \pm 32$ & $1948^{\mathrm{a}} \pm 42$ & $276.8^{\mathrm{abc}} \pm 11.5$ \\
$\mathrm{LE}$ & $250^{\mathrm{ab}} \pm 06$ & $632 \pm 24$ & $1023^{\mathrm{a}} \pm 32$ & $1904^{\mathrm{a}} \pm 49$ & $258.9^{\mathrm{a}} \pm 21.3$ \\
$\mathrm{HE}$ & $260^{\mathrm{abc}} \pm 08$ & $688 \pm 23$ & $1122^{\mathrm{bc}} \pm 35$ & $2062^{\mathrm{bc}} \pm 47$ & $322.2^{\mathrm{cd}} \pm 8.8$ \\
$\mathrm{NE}+20$ & $243^{\mathrm{a}} \pm 07$ & $653 \pm 28$ & $980^{\mathrm{a}} \pm 46$ & $1932^{\mathrm{ab}} \pm 53$ & $270.2^{\mathrm{ab}} \pm 27.2$ \\
$\mathrm{LE}+20$ & $253^{\mathrm{ab}} \pm 08$ & $629 \pm 24$ & $1030^{\mathrm{ab}} \pm 28$ & $1912^{\mathrm{a}} \pm 47$ & $268.2^{\mathrm{ab}} \pm 15.6$ \\
$\mathrm{HE}+20$ & $291^{\mathrm{d}} \pm 08$ & $702 \pm 15$ & $1136^{\mathrm{c}} \pm 41$ & $2129^{\mathrm{c}} \pm 49$ & $357.1^{\mathrm{d}} \pm 3.4$ \\
$\mathrm{NE}+40$ & $251^{\mathrm{ab}} \pm 08$ & $654 \pm 25$ & $969^{\mathrm{a}} \pm 38$ & $1910^{\mathrm{a}} \pm 47$ & $264.4^{\mathrm{a}} \pm 16.8$ \\
$L E+40$ & $265^{\mathrm{bc}} \pm 08$ & $595 \pm 26$ & $1039^{\mathrm{abc}} \pm 35$ & $1900^{\mathrm{a}} \pm 42$ & $268.8^{\mathrm{ab}} \pm 0.6$ \\
$\mathrm{HE}+40$ & $275^{\mathrm{cd}} \pm 09$ & $644 \pm 24$ & $1068^{\mathrm{abc}} \pm 36$ & $1987^{\mathrm{ab}} \pm 55$ & $314.2^{\mathrm{bcd}} \pm 4.7$ \\
$P$ value & 0.0005 & 0.07 & 0.009 & 0.005 & 0.001 \\
\hline
\end{tabular}

Means with atleast one common superscript in a column do not differ significantly $(P>0.05)$.

respective unsupplemented energy groups. Numerically the feed efficiency and production score was best in high energy diet supplemented with CoQ10 at $20 \mathrm{mg} /$ $\mathrm{kg}$.

\section{Slaughter parameters and ascites heart index}

The results of slaughter parameters - dressed weight, giblet weight, liver, spleen, gizzard weight, per cent of abdominal body fat and ascites heart index are presented in Table 6.

The CoQ10 supplementation did not affect the dressing per cent, giblet weight, gizzard, liver, spleen weight and intestinal length at various energy levels. Whereas, the weight of heart (per cent of body weight) was found to be significantly lower in low energy diet with $40 \mathrm{mg} / \mathrm{kg}$ of CoQ10 supplementation and high energy diet at $20 \mathrm{mg} / \mathrm{kg}$ of CoQ10 in diet over the respective unsupplemented groups. The abdominal fat percentage was significantly reduced by the CoQ10 supplementation at $40 \mathrm{mg} / \mathrm{kg}$ in both

Table 4 Influence of Coenzyme Q10 and energy each at three levels on feed intake $(g)$ at different growth phases

\begin{tabular}{ccccc}
\hline Treatments & $\mathbf{0 - 2}$ weeks & $\mathbf{3 - 4}$ weeks & $\mathbf{5 - 6}$ weeks & $\mathbf{0 - 6}$ weeks \\
\hline $\mathrm{NE}$ & $312 \pm 24$ & $970 \pm 18$ & $1930^{\mathrm{a}} \pm 80$ & $3212 \pm 72$ \\
$\mathrm{LE}$ & $322 \pm 34$ & $940 \pm 59$ & $2184^{\mathrm{d}} \pm 86$ & $3446 \pm 06$ \\
$\mathrm{HE}$ & $304 \pm 09$ & $874 \pm 15$ & $1931^{\mathrm{a}} \pm 41$ & $3217 \pm 45$ \\
$\mathrm{NE}+20$ & $287 \pm 25$ & $908 \pm 31$ & $1949^{\mathrm{a}} \pm 35$ & $3144 \pm 87$ \\
$\mathrm{LE}+20$ & $308 \pm 21$ & $897 \pm 60$ & $2134^{\mathrm{cd}} \pm 14$ & $3339 \pm 82$ \\
$\mathrm{HE}+20$ & $310 \pm 09$ & $853 \pm 19$ & $1931^{\mathrm{a}} \pm 72$ & $3094 \pm 73$ \\
$\mathrm{NE}+40$ & $304 \pm 18$ & $916 \pm 40$ & $2013^{\mathrm{abc}} \pm 58$ & $3233 \pm 52$ \\
$\mathrm{LE}+40$ & $322 \pm 05$ & $840 \pm 30$ & $2117^{\mathrm{bcd}} \pm 23$ & $3279 \pm 26$ \\
$\mathrm{HE}+40$ & $301 \pm 12$ & $793 \pm 28$ & $1974^{\mathrm{abc}} \pm 22$ & $3068 \pm 61$ \\
$\mathrm{P}$ value & 0.95 & 0.09 & 0.02 & 0.09 \\
\hline
\end{tabular}

Means with atleast one common superscript in a column do not differ significantly $(P>0.05)$. normal and high energy but not in low energy diet fed birds. CoQ10 supplementation at $20 \mathrm{mg} / \mathrm{kg}$ did not affect the abdominal fat percentage. The reduction in the abdominal fat at $40 \mathrm{mg}$ of CoQ10/ $\mathrm{kg}$ in normal and high energy diet might have been due to the better utilization of energy for muscle growth, however, the performance in terms of body weight gain nor feed efficiency were not significantly better in their groups. The intestinal length $(\mathrm{cm})$ expressed as per $\mathrm{kg}$ body weight was significantly lower in normal energy group supplemented with 20 and $40 \mathrm{mg}$ CoQ10/kg of diet but the length was not affected by both the levels of CoQ10 in low and high energy groups. No reason could be assigned for reduction in intestinal length in normal energy diet supplemented with CoQ10. In normal energy, CoQ10 supplementation did not affect the ascites heart index whereas low energy diet with $40 \mathrm{mg} / \mathrm{kg}$ CoQ10 supplementation and high energy diet with $20 \mathrm{mg} / \mathrm{kg}$ of diet CoQ10 supplementation, ascites heart index was significantly reduced over the unsupplemented groups.

\section{Cost effectiveness}

The feed cost of the different experimental feeds and the cost of feeding per kg of gain of CoQ10 supplementation at different energy levels are presented in Table 7.

The effect CoQ10 supplementation at different energy levels on feed cost per $\mathrm{kg}$ live weight gain was significantly low in high energy diet supplemented with CoQ10 at $20 \mathrm{mg} / \mathrm{kg}$ (₹. 49.83) and highest in normal energy supplemented with $40 \mathrm{mg} / \mathrm{kg}$ (₹. 56.16). The general trend was $20 \mathrm{mg} / \mathrm{kg}$ supplementation resulted in lower feed cost in all the three levels of energy over the corresponding energy unsupplemented and $40 \mathrm{mg} / \mathrm{kg}$ supplemented groups. However, only the low energy group supplemented with $40 \mathrm{mg} / \mathrm{kg}$ had lower cost of feeding than the corresponding energy unsupplemented group. 
Table 5 Influence of Coenzyme Q10 and energy each at three levels on feed efficiency of broilers at different growth phases

\begin{tabular}{ccccc}
\hline Treatments & $\mathbf{0 - 2}$ weeks & $\mathbf{3 - 4}$ weeks & $\mathbf{5 - 6}$ weeks & $\mathbf{0 - 6}$ weeks \\
\hline $\mathrm{NE}$ & $1.220 \pm 0.073$ & $1.445 \pm 0.047$ & $1.921^{\mathrm{abcd}} \pm .111$ & $1.706^{\mathrm{bcd}} \pm 0.044$ \\
$\mathrm{LE}$ & $1.308 \pm 0.179$ & $1.489 \pm 0.096$ & $2.145^{\mathrm{d}} \pm 0.146$ & $1.814^{\mathrm{d}} \pm 0.116$ \\
$\mathrm{HE}$ & $1.152 \pm 0.032$ & $1.273 \pm 0.036$ & $1.811^{\mathrm{ab}} \pm 0.018$ & $1.561^{\mathrm{abc}} \pm 0.019$ \\
$\mathrm{NE}+20$ & $1.164 \pm 0.109$ & $1.405 \pm 0.127$ & $2.006^{\mathrm{bcd}} \pm 0.139$ & $1.749^{c d} \pm 0.094$ \\
$\mathrm{LE}+20$ & $1.283 \pm 0.179$ & $1.438 \pm 0.144$ & $2.073^{\mathrm{bcd}} \pm .032$ & $1.749^{c \mathrm{~cd}} \pm 0.071$ \\
$\mathrm{HE}+20$ & $1.054 \pm 0.021$ & $1.215 \pm 0.023$ & $1.698^{\mathrm{a}} \pm 0.026$ & $1.453^{\mathrm{a}} \pm 0.024$ \\
$\mathrm{NE}+40$ & $1.250 \pm 0.123$ & $1.405 \pm 0.096$ & $2.085^{\mathrm{cd}} \pm 0.126$ & $1.755^{\mathrm{d}} \pm 0.078$ \\
$\mathrm{LE}+40$ & $1.229 \pm 0.043$ & $1.412 \pm 0.010$ & $2.037^{\mathrm{bcd}} \pm .020$ & $1.726^{\mathrm{bcd}} \pm 0.005$ \\
$\mathrm{HE}+40$ & $1.041 \pm 0.042$ & $1.231 \pm 0.024$ & $1.849^{\mathrm{abc}} \pm .043$ & $1.544^{\mathrm{ab}} \pm 0.012$ \\
$P$ value & 0.45 & 0.22 & 0.04 & 0.01 \\
\hline
\end{tabular}

Means with atleast one common superscript in a column do not differ significantly $(P>0.05)$.

\section{Discussion}

\section{Growth performance}

The non-significance in body weight gain on CoQ10 supplementation were also recorded by Geng et al. (2004a) in broilers, Honda et al. (2010) in growing chickens, Nakamura et al. (1996) using CoQ9 in broilers. However, Geng et al. (2007) reported that the broilers maintained at low environmental temperature (maximum temperature $-15^{\circ} \mathrm{C}$ and minimum $-12^{\circ} \mathrm{C}$ ), had significantly higher weight gain with comparable feed intake and feed efficiency when $40 \mathrm{mg}$ of CoQ10/ $\mathrm{kg}$ of diet was supplemented. Similarly, Huang et al. (2011) reared birds at $22^{\circ} \mathrm{C}$ also observed better weight gain between 0 to 21 days of age at 20 or $40 \mathrm{mg} / \mathrm{kg}$ of diet CoQ10 supplementation but the growth rate between 21 to 42 days was comparable. Krizman et al. (2012) suggested that continuous supplementation (1 to 42 days) of CoQ10 improved the body weight over the unsupplemented group (where no mention of the rearing temperature was indicated). The studies by Geng et al. (2007) and Huang et al. (2011) were carried out under lower environmental temperature which predisposes pulmonary hypertension syndrome (PHS) which leads to ventricular hypertrophy. This ventricular hypertrophy leads to reduced blood supply to various body tissues; a CoQ10 supplementation significantly reduced the

Table 6 Influence of Coenzyme Q10 and energy each at three levels on slaughter parameters

\begin{tabular}{|c|c|c|c|c|c|c|c|c|c|c|}
\hline Treatments & $\begin{array}{c}\text { Dressing } \\
\text { Percentage } \\
(\%)\end{array}$ & $\begin{array}{c}\text { Giblet } \\
\text { weight } \\
\text { (g) }\end{array}$ & $\begin{array}{c}\text { Gizzard } \\
\text { weight } \\
\text { (g) }\end{array}$ & $\begin{array}{l}\text { Liver } \\
\text { weight } \\
\text { (g) }\end{array}$ & $\begin{array}{l}\text { Heart weight } \\
\text { (g/kg body } \\
\text { weight) }\end{array}$ & $\begin{array}{c}\text { Abdominal } \\
\text { Fat (\% of } \\
\text { body weight) }\end{array}$ & $\begin{array}{l}\text { Spleen } \\
\text { weight } \\
\text { (g) }\end{array}$ & $\begin{array}{l}\text { Intestinal } \\
\text { Length } \\
(\mathrm{cm})\end{array}$ & $\begin{array}{c}\text { Intestine } \\
\text { length }(\mathrm{cm} / \mathrm{kg} \\
\text { body weight) }\end{array}$ & $\begin{array}{c}\text { Ascites Heart } \\
\text { Index (AHI) } \\
\text { (RV/TV) }\end{array}$ \\
\hline NE & $70.0 \pm 0.8$ & $\begin{array}{c}112.6 \pm \\
7.0\end{array}$ & $\begin{array}{c}42.3 \pm \\
2.0\end{array}$ & $\begin{array}{c}59.7 \pm \\
5.2\end{array}$ & $10.6^{\mathrm{ab}} \pm 0.4$ & $1.03^{b c} \pm 0.10$ & $3.2 \pm 0.4$ & $226.1 \pm 5.1$ & $112.2^{c} \pm 2.4$ & $0.255^{\mathrm{ab}} \pm 0.003$ \\
\hline LE & $70.1 \pm 0.6$ & $\begin{array}{c}98.0 \pm \\
2.9\end{array}$ & $\begin{array}{c}40.7 \pm \\
1.7\end{array}$ & $\begin{array}{c}46.1 \pm \\
2.2\end{array}$ & $11.2^{b c} \pm 0.6$ & $1.11^{b c} \pm 0.10$ & $2.9 \pm 0.4$ & $211.8 \pm 6.8$ & $101.9^{\mathrm{ab}} \pm 4.0$ & $0.261^{b c} \pm 0.005$ \\
\hline $\mathrm{HE}$ & $70.3 \pm 0.7$ & $\begin{array}{c}103.2 \pm \\
4.8\end{array}$ & $\begin{array}{c}39.1 \pm \\
1.0\end{array}$ & $\begin{array}{c}51.6 \pm \\
3.6\end{array}$ & $12.6^{c} \pm 0.8$ & $1.33^{d} \pm 0.22$ & $2.9 \pm 0.3$ & $223.2 \pm 5.1$ & $101.1^{\mathrm{ab}} \pm 3.5$ & $0.273^{c} \pm 0.007$ \\
\hline $\mathrm{NE}+20$ & $70.1 \pm 0.9$ & $\begin{array}{c}105.2 \pm \\
1.7\end{array}$ & $\begin{array}{c}37.7 \pm \\
1.4\end{array}$ & $\begin{array}{c}56.7 \pm \\
1.5\end{array}$ & $10.9^{b c} \pm 0.6$ & $0.90^{\mathrm{b}} \pm 0.07$ & $3.8 \pm 0.4$ & $222.9 \pm 4.8$ & $108.0^{\mathrm{ab}} \pm 2.8$ & $0.258^{b c} \pm 0.005$ \\
\hline $\mathrm{LE}+20$ & $70.0 \pm 0.9$ & $\begin{array}{c}101.7 \pm \\
2.5\end{array}$ & $\begin{array}{c}38.6 \pm \\
1.2\end{array}$ & $\begin{array}{c}52.2 \pm \\
1.9\end{array}$ & $10.9^{b c} \pm 0.8$ & $1.08^{b c} \pm 0.13$ & $3.7 \pm 0.5$ & $213.2 \pm 7.1$ & $103.0^{\mathrm{ab}} \pm 3.5$ & $0.258^{b c} \pm 0.007$ \\
\hline $\mathrm{HE}+20$ & $70.4 \pm 0.6$ & $\begin{array}{c}103.9 \pm \\
1.8\end{array}$ & $\begin{array}{c}37.7 \pm \\
1.1\end{array}$ & $\begin{array}{c}55.6 \pm \\
2.5\end{array}$ & $10.7^{\mathrm{ab}} \pm 0.8$ & $1.21^{c d} \pm 0.14$ & $2.6 \pm 0.4$ & $216.8 \pm 3.8$ & $98.0^{\mathrm{a}} \pm 1.7$ & $0.256^{\mathrm{ab}} \pm 0.007$ \\
\hline $\mathrm{NE}+40$ & $70.1 \pm 0.8$ & $\begin{array}{c}101.3 \pm \\
3.3\end{array}$ & $\begin{array}{c}37.4 \pm \\
1.6\end{array}$ & $\begin{array}{c}54.2 \pm \\
2.5\end{array}$ & $9.7^{\mathrm{ab}} \pm 0.6$ & $0.68^{a} \pm 0.09$ & $3.8 \pm 0.5$ & $216.5 \pm 4.7$ & $106.7^{b c} \pm 3.1$ & $0.248^{\mathrm{ab}} \pm 0.005$ \\
\hline $\mathrm{LE}+40$ & $70.2 \pm 0.8$ & $\begin{array}{c}97.0 \pm \\
4.8\end{array}$ & $\begin{array}{c}35.7 \pm \\
1.3\end{array}$ & $\begin{array}{c}52.4 \pm \\
3.9\end{array}$ & $8.9^{a} \pm 0.7$ & $1.07^{b c} \pm 0.15$ & $3.1 \pm 0.4$ & $223.1 \pm 4.3$ & $109.4^{\mathrm{bc}} \pm 3.5$ & $0.241^{a} \pm 0.006$ \\
\hline $\mathrm{HE}+40$ & $70.1 \pm 0.6$ & $\begin{array}{c}101.7 \pm \\
4.1\end{array}$ & $\begin{array}{c}38.9 \pm \\
1.3\end{array}$ & $\begin{array}{c}51.7 \pm \\
3.2\end{array}$ & $11.1^{b c} \pm 0.6$ & $0.96^{\mathrm{b}} \pm 0.11$ & $3.7 \pm 0.5$ & $214.2 \pm 3.2$ & $99.1^{a} \pm 4.1$ & $0.260^{b c} \pm 0.005$ \\
\hline$P$ value & 0.99 & 0.28 & 0.08 & 0.18 & 0.03 & 0.047 & 0.32 & 0.41 & 0.03 & 0.03 \\
\hline
\end{tabular}

Means with atleast one common superscript in a column do not differ significantly $(P>0.05)$. 
Table 7 Influence of Coenzyme Q10 and energy each at three levels on the cost of feed/kg live weight gain

\begin{tabular}{|c|c|c|c|c|c|c|c|c|c|}
\hline & NE & LE & $\mathrm{HE}$ & $\mathrm{NE}+20$ & $\mathrm{LE}+20$ & $\mathrm{HE}+20$ & $\mathrm{NE}+40$ & $\mathrm{LE}+40$ & $\mathrm{HE}+40$ \\
\hline \multicolumn{10}{|c|}{ Cost of feed/kg (Rs.) } \\
\hline Broiler 0-2 weeks diet & 33.22 & 31.85 & 34.59 & 33.31 & 31.95 & 34.69 & 33.41 & 32.04 & 34.79 \\
\hline Broiler 3-4 weeks diet & 33.19 & 31.65 & 34.25 & 33.29 & 31.74 & 34.35 & 33.39 & 31.84 & 34.45 \\
\hline Broiler 5-6 weeks diet & 32.86 & 31.47 & 34.11 & 32.95 & 31.57 & 34.20 & 33.05 & 31.66 & 34.30 \\
\hline $0-2$ weeks & 312 & 322 & 304 & 287 & 308 & 310 & 304 & 322 & 301 \\
\hline 3-4 weeks & 970 & 940 & 874 & 908 & 897 & 853 & 916 & 840 & 793 \\
\hline 5-6 weeks & 1930 & 2184 & 1931 & 1949 & 2134 & 1931 & 2013 & 2117 & 1974 \\
\hline Feed cost & 105.98 & 108.74 & 106.32 & 104.01 & 105.68 & 106.09 & 107.27 & 104.09 & 105.50 \\
\hline $0-6$ week body weight gain & 1948.38 & 1903.70 & 2061.63 & 1931.93 & 1912.33 & 2129.27 & 1910.00 & 1899.50 & 1987.27 \\
\hline $\begin{array}{l}\text { Feed cost/kg live weight* } \\
\text { (Rs.) }\end{array}$ & $\begin{array}{l}54.39^{\mathrm{e}} \pm \\
0.15\end{array}$ & $\begin{array}{l}57.12^{\mathrm{i}} \pm \\
0.05\end{array}$ & $\begin{array}{l}51.57^{\mathrm{b}} \pm \\
0.16\end{array}$ & $\begin{array}{l}53.84^{d} \pm \\
0.10\end{array}$ & $\begin{array}{l}55.26^{9} \pm \\
0.08\end{array}$ & $\begin{array}{c}49.83^{\mathrm{a}} \pm \\
0.19\end{array}$ & $\begin{array}{c}56.16^{\mathrm{h}} \pm \\
0.09\end{array}$ & $\begin{array}{c}54.80^{f} \pm \\
0.09\end{array}$ & $\begin{array}{c}53.09^{c} \pm \\
0.05\end{array}$ \\
\hline
\end{tabular}

Means with atleast one common superscript in a column do not differ significantly $(P>0.05)$.

ventricular hypertrophy (Table 6), the higher growth rate may be observed. In the present study, the birds were not under lower environmental temperature, hence no significant difference in growth rate could be observed. The level of CoQ10 did not influence the production score in the present study. However, Nakamura et al. (1996) reported higher production score when CoQ9 was supplemented, where the supplemented CoQ10 reduced the ascites mortality over the control as production score is directly proportional to survival rate. However, in the present study there no mortality of birds due to ascites or any other causes, hence the production score did not vary significantly as compared to Nakamura et al. (1996).

The higher feed intake in low energy diet might be due to the bird's trying to meet its energy requirement or to meet the critical amino acids lysine, methionine as the diets are formulated to contain the same ratio of energy : lysine; energy : methionine (since low energy diets contain low percentage of lysine and methionine). The feed efficiency was significantly better in high energy than other energy levels which coincide with the observation of Corduk et al. (2007). High energy diets to broilers help maximize energy intake and this higher energy intake maximizes the growth rate (Leeson and Summers 2001). High energy diet fed group had the highest production score than the normal and low energy diet fed groups. The higher production score might be due to higher body weight gain and better feed efficiency because the survival rate was uniform among all the groups.

\section{Slaughter parameters and ascites heart index}

The reduced relative heart weight ( $\mathrm{g} / \mathrm{kg}$ of body weight) was reported even at $20 \mathrm{mg} / \mathrm{kg}$ of CoQ10 by Huang et al. (2011) as his study was carried out at minimum temperature range of 19.69 to $22.21^{\circ} \mathrm{C}$, the right ventricle to total ventricle (RV/TV) was reduced by CoQ10 supplementation; hence the heart weight had reduced. This might be due to that CoQ10 offer some protection to cardiac myocytes of chicken as explained by Azuma et al. (1985). However, the increase in relative heart weight at $20 \mathrm{mg} / \mathrm{kg}$ (Geng et al. 2004a, 2004b and Geng et al. (2007) may be due to better growth performance, predispose to pulmonary hypertension, right ventricular hypertrophy and hence the heart muscle mass might have increased. Similar reduction in AHI due to CoQ10 supplementation was also reported by Azuma et al. (1985), Geng et al. 2004a, 2004b, Geng et al. (2007), Huang et al. (2011). The liver weight was significantly lower in low energy diet group similar to the observation of Cakir and Yalcin (2007) this might be due to enhanced lipogenesis in the liver (Router and Steele 1996; Swennen et al. 2006, Kamran et al. 2008) of birds fed with normal and high energy diet. Ayorinde (1994); Leeson et al. (1996); Raju et al. (2004); Nahashon et al. (2005) found that the per cent of abdominal fat was significantly increased as the dietary energy level increased. More fat deposition, due to the conversion of surplus energy to triglyceride and stored in adipose tissue as stated by Crespo and Gracia (2002). The widening of dietary calorie: protein ratio is also known to increases fat deposition in broilers. In the present study, increased abdominal fat in low energy diet has resulted even when the calorie: protein ratio was same in all treatments. The studies of Mateos et al. (1982) carried out with high fat supplemented ration were reported to reduce the intestinal tract length. This might be due to reduced rate of food passage in the gastro-intestinal tract when compared to birds fed without/less fat.

\section{Conclusion}

There is no significant effect of coenzyme Q10 as such in growth performance, slaughter parameters and cost 
effectiveness in broilers. The dietary supplementation of CoQ10 at $20 \mathrm{mg} / \mathrm{kg}$ in high energy diets leads to better body weight gain, feed efficiency and cost of production which might be an indication of energy - CoQ10 interaction in the body which needs further experiments to explore this.

\section{Competing interests}

The current study had no kind of conflict of interest. All authors confirm the above statement.

\section{Authors' contribution}

MG, MRP, DC were involved in selection of research topic and design of the broiler experiment. MG carried out the broiler trial, data collection, analysis and interpretation of data and prepared the first draft of the manuscript. MRP and DC assisted MG at all stages of this research work. MRP and DC revised the manuscript. All authors read and approved the final manuscript.

\section{Acknowledgement}

The authors wish to express their gratitude to Tamil Nadu Veterinary and Animal Sciences University, Chennai for the financial support to carry out this study.

\section{Received: 9 April 2014 Accepted: 25 August 2014}

Published: 11 September 2014

\section{References}

Alleva R, Tomasetti M, Bompadre S, Littaru P (1997) Oxidation of LDL and their subfractions: kinetic aspects and CoQ10 content. Mol Aspects Med 18:105-112

Ayorinde KL (1994) Effects of genotype and dietary energy on performance of broilers. Nigerian J Anim Prod 21:5-10

Azuma J, Harada H, Sawamura A, Ohta H, Awata H, Yamauchi K, Kishimoto S, Sperelakis N (1985) Beneficial effect of coenzyme Q on myocardial slow action potentials in hearts subjected to decreased perfusion pressure hypoxia -substrate - free perfusion. Basic Res Cardiol 80:147-155

Bautista-Ortega J, Ruiz-Feria CA, Ellis A (2010) Cytochemical and immunocytochemical localization of oxidative and nitrosative stress in pulmonary hypertension in lungs of broiler chickens, Gallus domesticus. Microscopy Microanalysis 16(S2):964-965

Cakir S, Yalcin S (2007) Effects of L-carnitine supplementation in diets with low or normal energy level on growth performance and carcass traits in broilers. Revuede Medecine Veterinaire 158:291-296

Cardoso AR, Cabral-Costa JV, Kowaltowski AJ (2010) Effects of a high fat diet on liver mitochondria: increased ATP-sensitive $\mathrm{K}$ channel activity and reactive oxygen species generation. J Bioenergetics Biomembranes 42:245-253

Corduk M, Ceylan N, Ildiz F (2007) Effects of dietary energy density and Lcarnitine supplementation on growth performance, carcass traits and blood parameters of broiler chickens. South African J Anim Sci 37(2):65-73

Crespo N, Gracia E (2002) Dietary poly unsaturated fatty acids decrease fat deposition in separable fat depots but not in the remainder carcass. Poult Sci 81:512-518

Duncan DB (1955) Multiple range and multiple ' $F$ ' test. Biometrics 11:1-42

Forstmark-Andre P, Lee CP, Dallner G, Ernster L (1997) Lipid peroxidation and changes in the ubiquinone content and the respiratory chain enzymes of submitochondrial particles. Free Radical Biol Medicine 22:391-400

Geng AL, Guo YM, Yang Y (2004a) Reduction of ascites mortality in broilers by coenzyme Q10. Poult Sci 83:1587-1593

Geng A, Guo Y, Yuan J (2004b) Effects of dietary L-carnitine and coenzyme Q10 supplementation on performance and ascites mortality of broilers. Arch Anim Nutr 58:473-482

Geng A, Li B, Guo Y (2007) Effects of dietary L-carnitine and coenzyme Q10 at different supplemental ages on growth performance and some immune response in ascites- susceptible broilers. Arch Anim Nutr 61:50-60

Honda K, Kamisoyama H, Motoori T, Saneyasu T, Hasegawa S (2010) Effect of dietary coenzyme Q10 on cholesterol metabolism in growing chickens. Japan Poult Sci 47:41-47

Huang B, Yuming G, Xiaofei H, Song Y (2011) Effects of coenzyme Q10 on growth performance and heart mitochondrial function of broilers under high altitude induced hypoxia. J Poult Sci 48:40-46
Huchzermeyer FW, Ruyck AMW (1986) Pulmonary hypertension syndrome associated with ascites in broilers. Vet Rec 119:94

Kamran Z, Sarwar M, Nisa MA, Nadeem S, Mahmood M, Babar E, Ahmed S (2008) Effect of low-protein diets having constant energy-to-protein ratio on performance and carcass characteristics of broiler chickens from one to thirty five days of age. Poult Sci 87(3):468-474

Krizman PJ, Prosek M, Smidovnik A, Wondra AG, Glaser R, Zelenko B, Volk M (2012) Poultry products with increased content of CoQ10 prepared from chickens fed with supplemental CoQ10. Ch. $9^{\text {th }}$. In: Eissa AHA (ed) Trends in Vital Food and control engineering. InTech, Rijeka, Croatia, pp 165-186

Lakomkin VL, Konovalova GG, Kalenikova El, Zabbarova IV, Kaminnyi Al, Tikhaze AH, Lankin VZ, Ruuge EK, Kapelko VI (2005) Changes in antioxidant status of myocardium during oxidative stress under the influence of coenzyme $\mathrm{Q}$. Biochemistry 70:79-84

Leeson S, Summers JD (2001) Scott's Nutrition of the Chicken. University Books Inc, Ontarion, Canada

Leeson S, Caston L, Summers JD (1996) Broiler responses to diet energy. Poult Sc 75:529-535

Mateos GG, Sell JL, Eastwood JA (1982) Rate of food passage as influenced by level of supplemental fat. Poult Sci 61:94-100

Nahashon S, Adefope N, Amenyenu A, Wright D (2005) Effects of dietary metabolizable energy and crude protein concentrations on growth performance and carcass characteristics of French guinea broilers. Poult Sci 84:337-344

Nakamura K, Noguchi K, Aoyama T, Nakajlma T, Tanimura N (1996) Protective effect of ubiquinone (coenzyme Q9) on ascites in broiler chickens. Br Poult Sci 37:189-195

Navas P, Villalba JM, Cabo RD (2007) The importance of plasma membrane coenzyme $Q$ in aging and stress responses. Mitochondrion 7S:34-40

Ozkan S, Takma C, Yahav S, Sogut B, Turkmut L, Erturun H, Cahaner A (2010) The effects of feed restriction and ambient temperature on growth and ascites mortality of broilers reared at high altitude. Poult Sci 89:974-985

Raju MV, Sunder GS, Chawak M, Rao SVR, Sadagopan W (2004) Response of naked neck (Nana) and normal (nana) broiler chickens to dietary energy level in a subtropical climate. Br Poult Sci 45:186-193

Router RW, Steele NC (1996) Energy and protein relations in the broiler. 1. Effect of protein levels and feeding regimes on growth, body composition and in-vitro lipogenesis in broiler chickens. Poult Sci 64:119-126

Saber NS, Maheri-Sis N, Shaddel-Telli A, Hatefinezhad K, Gorbani A, Yousefi J (2011) Effect of feed restriction on growth performance of broiler chickens. Annals of Biol Res 2(6):247-252

Schmidt CJ, Persia ME, Ferierstein E, Kingham B, Saylor WW (2009) Comparison of a modern broiler line and a heritage line unselected since the 1950s. Poult Sci 88:2610-2619

Shi-bin Y, Dai-wen C, Keying Z, Bing Z (2007) Effects of oxidative stress on growth performance, nutrient digestibilities and activities of antioxidative enzymes of weanling pigs. Asian-Australian J Anim Sci 20(10):1600-1605

Snedecor GW, Cochran WG (1989) Statistical Methods, 8th edn. lowa state university press, Ames, USA, p lowa - 50010

Suzuki K, Shibata Y (1989) Evaluation of production score, an index of broiler management. Res Bull Aichi Agricultural Res Centre 21:410-414

Swennen Q, Janssens A, Collin E, Bihan-Duval L, Verbeke K, Decuypere E, Buyse K (2006) Diet-induced thermogenesis and glucose oxidation in broiler chickens: influence of genotype and diet composition. Poult Sci 85:731-742

Tang PH, Miles MV, Degrauw A, Hershey A, Pesce A (2001) HPLC analysis of reduced and oxidized coenzyme Q10 in human plasma. Clin Chem 47:256-265

Tao X, Xin H (2003) Acute synergistic effects of air temperature, humidity and velocity on homeostasis of market-size broilers. Trans Am Soc Agric Eng 46(2):491-497

Vicas SI, Lasio V, Uivarosan D (2009) Stimulation of biosynthesis of coenzyme Q10 by Sacharomyces cerevisiae under the influence of vitamin B1. Analele Universitatii Din Oradea 2:693-700

Zhan XA, Wang M, Ren H, Zhao RQ, Li JX, Tan ZL (2007) Effect of early feed restriction on metabolic programming and compensatory growth in broiler chickens. Poult Sci 86(4):654-660

doi:10.1186/2193-1801-3-518

Cite this article as: Gopi et al.: Effect of dietary coenzyme Q10 supplementation on the growth rate, carcass characters and cost effectiveness of broiler fed with three energy levels. SpringerPlus 2014 3:518. 